AUTHOR CORRECTION

\title{
Author Correction: Deep learning analysis of defect and phase evolution during electron beam-induced transformations in $\mathrm{WS}_{2}$
}

Artem Maksov (D), Ondrej Dyck, Kai Wang (D), Kai Xiao, David B. Geohegan, Bobby G. Sumpter, Rama K. Vasudevan, Stephen Jesse, Sergei V. Kalinin and Maxim Ziatdinov

npj Computational Materials (2020)6:15; https://doi.org/10.1038/s41524-020-0285-x

Correction to: npj Computational Materials https://doi.org/ 10.1038/s41524-019-0152-9, published online 1 February 2019

The original version of the published Article omitted a statement from the Acknowledgements section. The Acknowledgements have been updated to include the following: The work on microscopy and synthesis was supported by the U.S. Department of Energy, Office of Science, Basic Energy Sciences, Materials Sciences and Engineering Division (R.K.V., S.V.K., K.W., K.X., D.G.). The HTML and PDF versions of the Article have been corrected.

\begin{abstract}
(c) (i) Open Access This article is licensed under a Creative Commons Attribution 4.0 International License, which permits use, sharing, adaptation, distribution and reproduction in any medium or format, as long as you give appropriate credit to the original author(s) and the source, provide a link to the Creative Commons license, and indicate if changes were made. The images or other third party material in this article are included in the article's Creative Commons license, unless indicated otherwise in a credit line to the material. If material is not included in the article's Creative Commons license and your intended use is not permitted by statutory regulation or exceeds the permitted use, you will need to obtain permission directly from the copyright holder. To view a copy of this license, visit http://creativecommons. org/licenses/by/4.0/.
\end{abstract}

This is a U.S. government work and not under copyright protection in the U.S.; foreign copyright protection may apply 2020 